\title{
Determination of the distribution and abundance of the limpet Scurria scurra on the stipes of the kelp Lessonia nigrescens in Central Chile
}

\author{
Mauricio Muñoz, Bernabé Santelices* \\ Departamento de Ecologia, Facultad de Ciencias Biológicas, P. Universidad Católica de Chile, Casilla 114-D, Santiago, Chile
}

\begin{abstract}
In Central Chile, the limpet Scurria scurra lives in open cavities on the stipes of the kelp Lessonia nigrescens. Several characters in this association, including number of limpets per cavity and number and position of cavities along the stipes, are highly fixed. In this study we use explanations suggested elsewhere for equivalent specific patterns in other limpet-kelp associations as testable hypothesis for the Scurria-Lessonia relationship. Results indicate that the limpet has a highly predictable location in the kelp bed, decreasing in abundance with decreasing tide levels and with increasing time exposed to waves. Usually one limpet is found per scar and only one scar per stipe, generally excavated under the first stipe bifurcation. Limpets can wander out of the cavities during high tides. They show no significant ontogenic changes in radular structure or in excavating capacities. They could occupy any new suitable stipe once they are dislodged due to accidents while wandering out of the cavity or because of stipe breakage. In addition, close to $20 \%$ of the limpet population survives stipe breakage by remaining attached to the stipe stumps. Field experiments indicate that friction between the stipes of $L$. nigrescens is the most important factor determining the number and distribution of cavities on the stipes. A comparison of our findings with results on other limpet-kelp associations indicate that generalizations are restricted to a few common features only. In each association there are several additional specific characters which seemingly represent the outcome of specific life history adjustments of each interacting partner.
\end{abstract}

\section{INTRODUCTION}

In Central Chile, the limpet Scurria scurra Lesson inhabits the stipes of the kelp Lessonia nigrescens Bory. The relationship seems to be obligate and specialized. For example, S. scurra is rarely found on rocks or other algae, and only infrequently can be found on the bull kelp Durvillaea antarctica (Chamisso) Hariot, which sometimes co-exists with L. nigrescens. Limpets smaller than $5 \mathrm{~mm}$ live in small galleries excavated in the kelp holdfast while larger individuals bore open cavities into the stipes. Previous studies (Santelices et al. 1980), as well as field observations, indicate that the number of limpets per cavity, as well as the position of the cavities, were highly constant. In general there is one limpet per stipe, although occasionally up to 4 may be found in successive cavities along a given stipe. Cavities are bored on the proximal part of the stipe or at the first stipe bifurcation.

\footnotetext{
- Addressee for reprint requests
}

Some evidence (Santelices et al. 1980) suggests that this kelp-limpet association might increase algal survival. Stipes tend to break at the cavities, so it is thought that limpets have a 'pruning effect' leading to selective losses of the largest and heaviest stipes rather than of the entire plant. However, what benefit, other than food and shelter, could be obtained by the limpet in this relationship is unknown, as is the level of limpet mortality due to algal breakage during storms. Indeed, the fate of the limpet after stipe losses is completely unknown.

Three other kelp-limpet associations have been studied in temperate areas of the world. In England, the limpet Helcion pellucidus lives on fronds or holdfasts of Laminaria hyperborea or Saccorhiza polyschides (Graham \& Fretter 1947, Kain 1963, Vahl 1971, 1972). On the west coast of the United States, Notoacmea insessa inhabits the fronds of Egregia laevigata (Black 1974, 1976, Choat \& Black 1979) while in South Africa, Patella compressa settles and lives in the stipes of Ecklonia maxima (Branch 1975a, 1985). A 
comparison of these 3 cases (Table 1) shows that some patterns in these associations parallel those observed in Central Chile and the pertinent explanations could be used as testable hypotheses for the Scurria scuraLessonia nigrescens relationship: (1) the restriction of the herbivore to a precise part of the plant could result from heterogeneous distribution of chemical deterrents in the plant (Choat \& Black 1979); (2) territorial behavior could restrict the number of individuals inhabiting a stipe, thus reducing interspecific competition (Branch 1975b, 1976); (3) age-related differences in radular structure or in excavating capacities could indicate ontogenetic changes in trophic specialization (Steneck 1982); and (4) the recruitment of juveniles in previously excavated cavities might reflect incapacity to make the grazing scars quickly (Black 1976).

In this study we sought such patterns in the Scurria scurra-Lessonia nigrescens interaction in Central Chile and an explanation for them. Using larger samples and a different kelp population than in a previous study (Santelices et al. 1980), we first evaluated the distributional patterns and consistency of some characters, such as limpet distribution in the kelp zone and in the plant, number of limpets per stipe and cavity, and morphometric relations among limpet, stipe, and cavity. Then we looked for temporal changes in these patterns, including age-related changes in radular structure and in excavating capacities of the limpet, as well as limpet mortality during high tide and after stipe breakage. Finally, we conducted some field experiments to test for the ecological factors most likely determining the fixed number and position of limpets on the stipes and in the cavities.

\section{MATERIALS AND METHODS}

The study site was a wave-exposed area of rocky platforms at Pelancura, $5 \mathrm{~km}$ north of San Antonio Port, in Central Chile. These intertidal-subtidal boundaries are numerically dominated by the kelp Lessonia nigrescens with a vertical distribution ranging from 2 to $10 \mathrm{~m}$, depending on the slope of the rock.

Patterns of distribution of Scurria scurra on Lessonia nigrescens. The pattern of distribution and abundance of limpets across the Lessonia bed was studied using 3 linear transects $(3,4$ and $8 \mathrm{~m}$ total length), extending from the uppermost to the lower-

Table 1. Common and contrasting features in 3 cases of limpet-kelp associations

\begin{tabular}{|c|c|c|c|}
\hline Features & $\begin{array}{l}\text { Helcion pellucidus } \\
\text { on Laminaria sp. }\end{array}$ & $\begin{array}{l}\text { Notoacmea insessa } \\
\text { on Egregia laevigata }\end{array}$ & $\begin{array}{l}\text { Patella compressa } \\
\text { on Ecklonia maxima }\end{array}$ \\
\hline $\begin{array}{l}\text { Precise limpet location in the } \\
\text { kelp bed }\end{array}$ & Not described & No precise location & Not described \\
\hline $\begin{array}{l}\text { Precise limpet location in the } \\
\text { plant }\end{array}$ & Fronds and holdfasts & Stipes and rachis & Stipes \\
\hline Place of limpet recruitment & Fronds & Scars on old rachis & Folds at the base of fronds \\
\hline $\begin{array}{l}\text { Minimum size of reproducing } \\
\text { limpets }\end{array}$ & Less than 5 mo & $6 \mathrm{~mm}$ & Unknown \\
\hline $\begin{array}{l}\text { Maximum limpet size } \\
\text { (Growth rate) }\end{array}$ & $5 \mathrm{~mm}$ (high) & $18 \mathrm{~mm}$ (very high) & $75 \mathrm{~mm}$ (low) \\
\hline Reproduction & Permanent through the year & Permanent through the year & Unknown \\
\hline Territorial behaviour & Not described & Not described & Inter-adults \\
\hline Limpet motility & $\begin{array}{l}\text { Limpets migrate between } \\
\text { holdfasts and fronds }\end{array}$ & $\begin{array}{l}\text { Low. Leave old scars and } \\
\text { make new ones }\end{array}$ & High. Along the stipe \\
\hline Excavation of open cavities & On the cortical tissues & On the cortical tissue & $\begin{array}{l}\text { No cavity. Some superficial } \\
\text { damage }\end{array}$ \\
\hline $\begin{array}{l}\text { Limpet-induce damage on } \\
\text { algal meristematic or (repro- } \\
\text { ductive) tissues }\end{array}$ & $\begin{array}{l}\text { No } \\
\text { (No) }\end{array}$ & $\begin{array}{l}\text { No } \\
\text { (No) }\end{array}$ & $\begin{array}{l}\text { No } \\
\text { (No) }\end{array}$ \\
\hline $\begin{array}{l}\text { Age differences in excavating } \\
\text { capacities }\end{array}$ & Not reported & $\begin{array}{l}\text { Yes. Small limpets }(<3 \mathrm{~mm}) \\
\text { cannot excavate }\end{array}$ & Not reported \\
\hline $\begin{array}{l}\text { Limpet mortality due to algal } \\
\text { removal }\end{array}$ & $\begin{array}{l}\text { High. Seasonal frond shed- } \\
\text { ding }\end{array}$ & $\begin{array}{l}\text { High. Water movement } \\
\text { removals }\end{array}$ & High. During winter storms \\
\hline $\begin{array}{l}\text { Fate of limpets after seaweed } \\
\text { is broken }\end{array}$ & $\begin{array}{l}\text { Attachment to holdfast } \\
\text { cavities }\end{array}$ & $\begin{array}{l}\text { Death by desiccation on sea- } \\
\text { weed cast ashore }\end{array}$ & $\begin{array}{l}\text { Death by desiccation on sea- } \\
\text { weed cast ashore }\end{array}$ \\
\hline
\end{tabular}


most vertical limit of the bed. Maximum holdfast diameter, number of broken and entire stipes and the number of limpets on each stipe were measured for each kelp plant intercepted by the transect.

In the part of the kelp population with maximum limpet density, 38 individuals of Lessonia nigrescens were haphazardly selected and sampled to measure the precise position of Scurria scurra on the plant, and the morphometric characters of the plants hosting limpets. Samplings included maximum holdfast diameter, number of entire and broken stipes, and number of stipes with excavated cavities, with or without limpets. In 78 of the stipes with limpets, measurements also included distance between the holdfast and the first dichotomy of the stipe, stipe diameter $2 \mathrm{~cm}$ above the holdfast, distance between the holdfast and the lower border of the excavated cavity, maximum shell diameter of the limpet and maximum depth and length of the cavity.

Temporal changes. Differences in radular structure were compared among 32 limpets with maximum shell diameters ranging from $0.1 \mathrm{~cm}$ to $3.7 \mathrm{~cm}$. Radulae were dissected and photographed under a Nikon stereomicroscope and drawn using a camera lucida.

Differences in excavating capacities were evaluated experimentally in the field using 2 groups of 10 limpets. One group included individuals of less than $2 \mathrm{~cm}$ in maximum shell diameter; the second group were limpets from 2 to $3.5 \mathrm{~cm}$ in shell diameter. Individuals were placed on randomly selected entire stipes, at about the same distance from the holdfast. These stipes were tagged as described in Santelices et al. (1980). The length and depth of the cavities excavated by each transplanted limpet were measured 6, 14 and $29 \mathrm{~d}$ after the beginning of the experiment.

Limpet motility was measured for $1 \mathrm{~h}$ during low and high tide, by recording through direct observation the distance along a given stipe between a given limpet and its corresponding cavity. The same previously tagged individuals were observed during low and high tides.

A total of 236 broken stipes were examined looking for limpet survival. The number of stipes still holding limpets within the scars was recorded. Stipes with clear evidence of limpet scars at the breaking points were distinguished from other broken stipes.

Experimental evaluation of factors. Two experiments were performed to test whether the precise position of Scurria scurra along the stipe may be significantly affected by interstipe friction induced by water movement. Experiments were conducted on 5 haphazardly selected comparable plants. One stipe of each plant of comparable length and thickness, and bearing $S$. scurra scars, was chosen. One limpet was placed $5 \mathrm{~cm}$ above and another $5 \mathrm{~cm}$ below the first stipe bifurcation. Limpet survival was evaluated after 1 tidal cycle.

The degree of inter-stipe friction was estimated by placing cocktail sticks (4 $\mathrm{cm}$ long, $2 \mathrm{~mm}$ diameter) along the stipe margins. From the kelp bed sector with maximum limpet abundance, 5 plants were haphazardly selected for the experiment. Thirty stipes, of comparable length and thickness, were selected in each plant, 15 with and 15 without limpet scars. Cocktail sticks were inserted every $5 \mathrm{~cm}$, to half their total length, in an alternate manner along both stipe borders, from the holdfast to the first stipe dichotomy. The same number of sticks was similarly inserted along the stipe portion arising from the first dichotomy. The number of sticks broken, lost or producing a noticeable wound on the stipe were recorded in each of the 30 stipes, 1 tidal cycle after the beginning of the experiment

The effect of territorial behavior on the number of individuals per cavity was tested placing 1 to 3 limpets in empty cavities. Small $(<2 \mathrm{~cm}$ shell diameter) and large individuals $(>2 \mathrm{~cm})$ were placed in various combinations of sizes and numbers in cavities large enough as to receive one more limpet than the number actually used in the experiment. The stipes used were of similar size and with cavities at similar distances from the holdfasts. The number and sizes of the limpet still living in each of the cavities was recorded $7 \mathrm{~d}$ after the beginning of the experiment.

The effects of territorial behavior and inter-stipe frictions on the number of Scurria scurra along a given stipe were tested on stipes without any evidence of previous limpet action, which were tagged in each one of 20 plants. In 10 of these plants, the remaining stipes were cut $2 \mathrm{~cm}$ above the holdfast. In the other 10 plants (control) they were left untouched. A total of 10 to 15 limpets, ranging from 1.0 to $3.0 \mathrm{~cm}$ in shell diameter, were regularly distributed at equal distance between the holdfast and the first stipe dichotomy of each tagged stipe. The number and position of the limpets in each of the 20 stipes was recorded 6, 14 and $29 \mathrm{~d}$ after the beginning of the experiment.

\section{RESULTS}

\section{Patterns of distribution of Scurria scurra on Lessonia nigrescens}

The patterns of distribution of limpets and broken stipes were very similar in 3 transects studied (Fig. 1). The presence of limpets ( 4 to 6 per plant) and broken stipes (30 to $40 \%$ per plant) became evident at the uppermost $0.5 \mathrm{~m}$ of the Lessonia band. Abundance values increased to a maximum ( 8 or 9 limpets and 40 


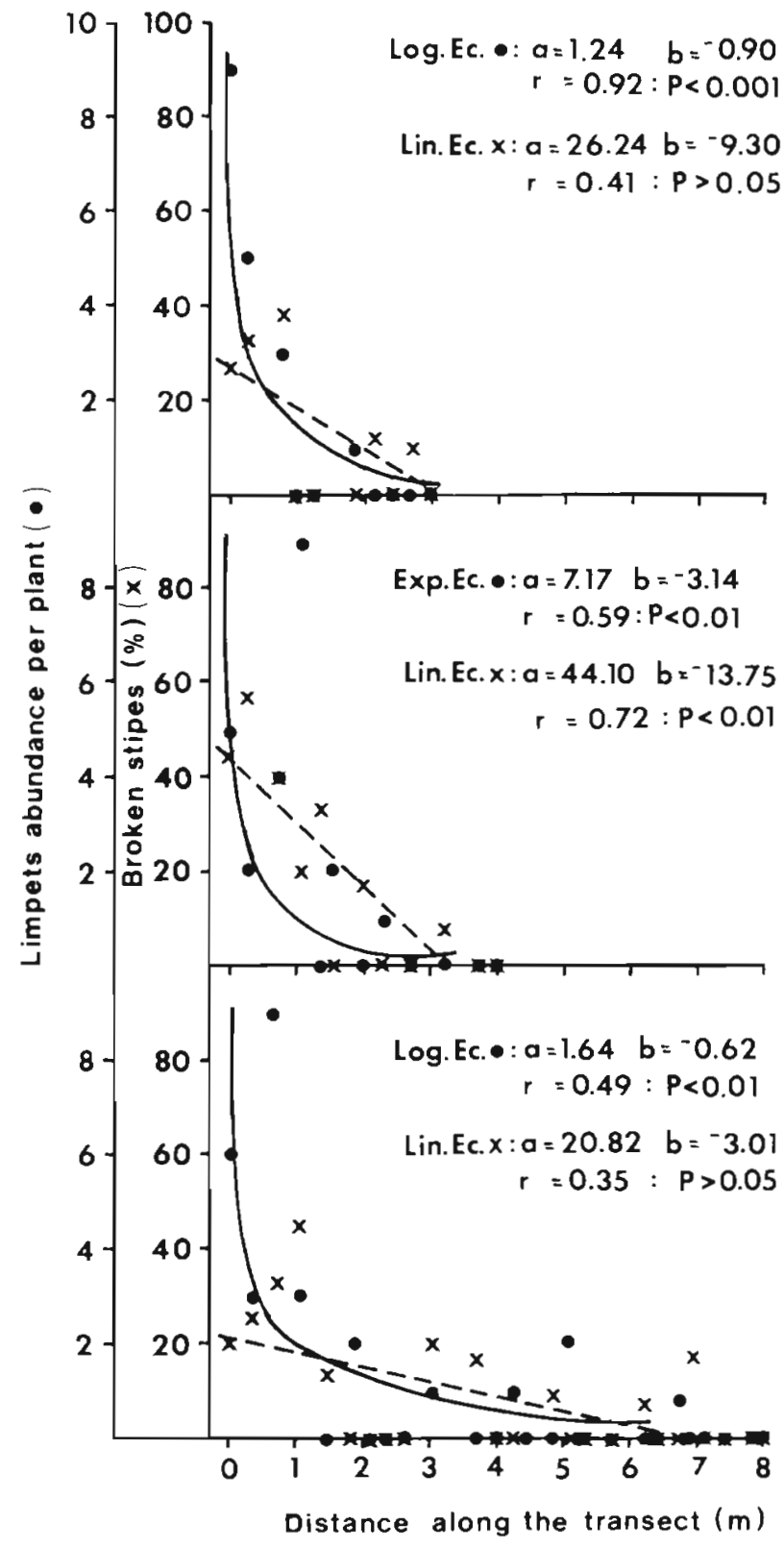

Fig. 1. Scurria scurra on Lessonia nigrescens. Number of limpets and percentage of broken stipes per plant as a function of distance along 3 transects extending from the upper to the lower (most wave-exposed) end of the kelp bed

to $60 \%$ broken stipes per plant) in the next 0.5 to $1.0 \mathrm{~m}$, then significantly decreased towards the most waveexposed end of the belt. These intertidal-shallow subtidal beds are not as deep as to receive attenuated wave action at their seaward ends. Thus, the seaward end is the most wave-exposed part of the belt.

Within the 0.5 to $1.5 \mathrm{~m}$ of the kelp bed with limpets present, small plants $(<8 \mathrm{~cm}$ of holdfast diameter) did not have limpets (Fig. 2). Larger plants had between 70 and $95 \%$ of their stipes either broken or with live

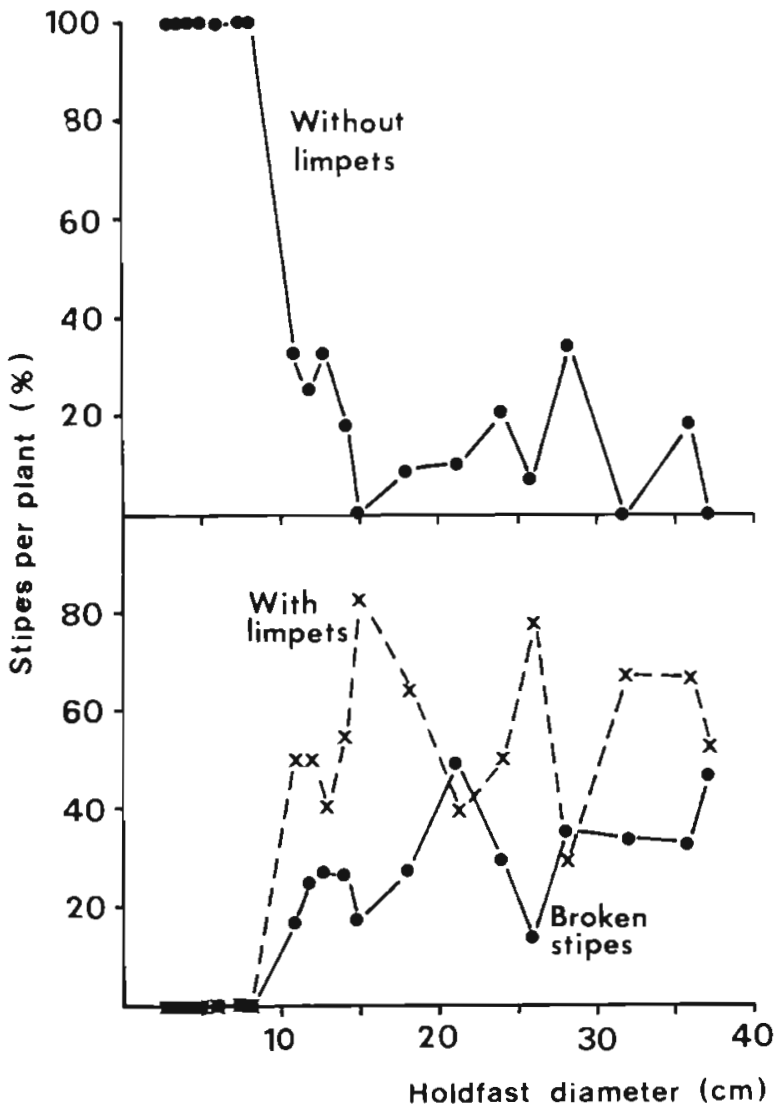

Fig. 2. Lessonia nigrescens. Number of stipes without limpets, with limpets in cavities and broken stipes in the 0.5 to $1.5 \mathrm{~m}$

zone of the kelp bed, as a function of holdfast diameter

limpets in the excavated cavities. Of 236 broken stipes, $182(77.1 \%)$ had limpet scars. We were unable to determine whether other factors were responsible for the breakage of the remaining $22.9 \%$ of the stipes or if their scars were no longer visible.

Out of 78 stipes with live limpets, $82 \%$ hosted only 1 limpet; in $14 \%, 2$ limpets were found in their corresponding cavities along a given stipe; and the remaining $4 \%$ contained 3 limpets each. In all cases $(n=95)$ there was only 1 limpet per cavity.

Limpets and cavities occur at a very precise part of the plant (Fig. 3), below the first dichotomy. In 73 stipes measured, not a single cavity was found above the first dichotomy. Small (less than $2 \mathrm{~cm}$ long) cavities were found close to the holdfast, irrespective of the total length of the portion of the stipe between the holdfast and the first dichotomy.

The size of the limpet (maximum shell diameter) had no relation (Fig. 4) to stipe diameter ( $r=0.087, p=0.42$, $n=93$ ). Both large and small limpets were found on stipes of different diameter. When living on narrow stipes, large limpets tend to excavate longer cavities, 


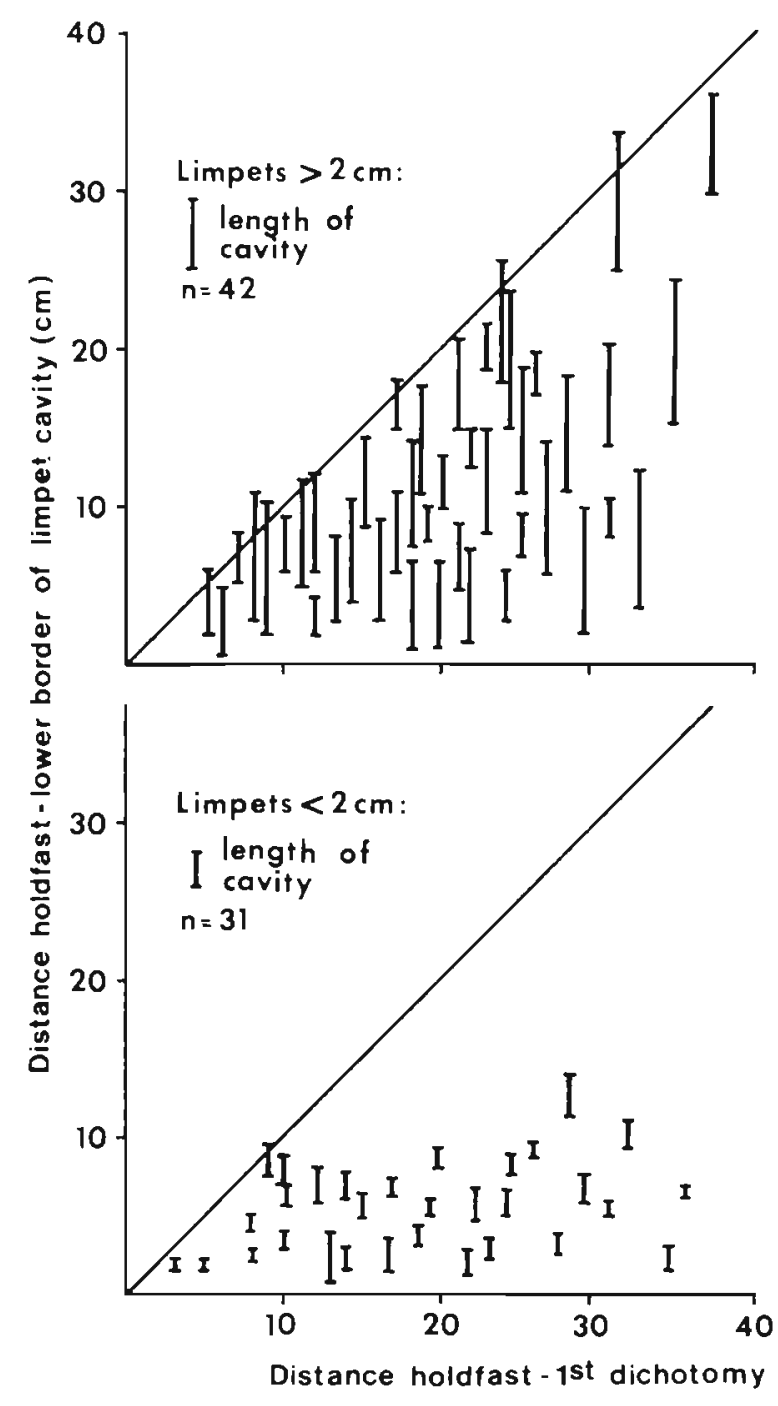

Fig. 3. Lessonia nigrescens. Pattern of distribution of limpet cavities along the kelp stipes

therefore, the length to depth ratio of the cavity tends to increase (Fig. 4) with increasing limpet size. When living on wider stipes, large limpets tend to bore deeper cavities and the length:depth ratio of the cavity tends to decrease. Thus, the size of the excavated cavity (surface reaction in Fig. 4) is a function of the size of the limpet and the diameter of the stipe.

In summary, data on patterns of distribution of Scurria scurra on Lessonia nigrescens indicate that the limpets have a highly predictable location in the kelp bed, decreasing in abundance with increasing wave exposure. They occur in plants larger than $8 \mathrm{~cm}$ holdfast diameter, in 30 to $70 \%$ of the stipe, always below the first stipe dichotomy, generally 1 individual per stipe and always 1 limpet per cavity. Cavity size is a function of limpet size and stipe thickness.

\section{Temporal changes}

No significant differences in radular structure were found among different sized individuals of Scurria scurra (Fig. 5). As the limpets grow, their radular teeth increase in size, but there are no other obvious changes. After $6 \mathrm{~d}$ of experiment, small limpets $<2$ $\mathrm{cm}$ ) excavated cavities $0.72 \pm 0.04 \mathrm{~cm}$ deep, while those excavated by larger limpets $(>2 \mathrm{~cm})$ were $0.65 \pm$ $0.07 \mathrm{~cm}$ deep. On the 29th day of the experiment, large limpets had excavated a proportionally longer cavity $(\overline{\mathrm{x}}=4.81 \pm 1.31 \mathrm{~cm})$ than small limpets $(\overline{\mathrm{x}}=2.10 \pm$ $0.42 \mathrm{~cm}$ ) but differences in depth between the groups of limpets were not significant (Fig. 6). In addition to quantifying the excavating capacities of limpet of different sizes, this experiment also showed that any limpet of any size arriving on a suitable stipe could excavate its cavity de novo within $30 \mathrm{~d}$. This is an important point to be considered when analysing the fate of limpets after stipe breakage.

Field observations on the limpet motility showed that they remained in the cavities during low tides. In contrast, 40 to $55 \%$ of the limpets observed for 1 h during high tides were found along the stipe at distances of 0 to $6 \mathrm{~cm}$ from the border of their corresponding cavities, indicating that they can move out of their cavities during high tides.

Counts on broken stipes indicated that $20.3 \%$ of 182 broken stipes with limpet scars contained live limpets which had remained inside the disrupted cavity, attached to the stipe stumps.

In summary, the study of temporal changes suggests that limpets can wander out of their cavities during high tides. Limpets do not exhibit significant ontogenic changes in radular structure or in excavating capacities and seemingly they could occupy, if suitable, any new stipe once they are dislodged from the stipe they inhibited either due to accidents while wandering out of the cavity or because of stipe breakage. In addition, $20 \%$ of the limpet population survives stipe breakage by remaining attached to the stipe stumps.

\section{Experimental evaluation of factors}

Experimental results with large and small limpets placed above and below the first stipe dichotomy indicate $100 \%$ losses for limpets placed above the dichotomy irrespective of limpet size (Fig. 7). Losses decrease to 20 to $40 \%$ when limpets are placed below the first dichotomy

These results are consistent with losses of cocktail sticks in stipes with and without limpet scars (Fig. 8). Close to $70 \%$ of the sticks inserted below the first stipe bifurcation in stipes with previous limpet scars per- 


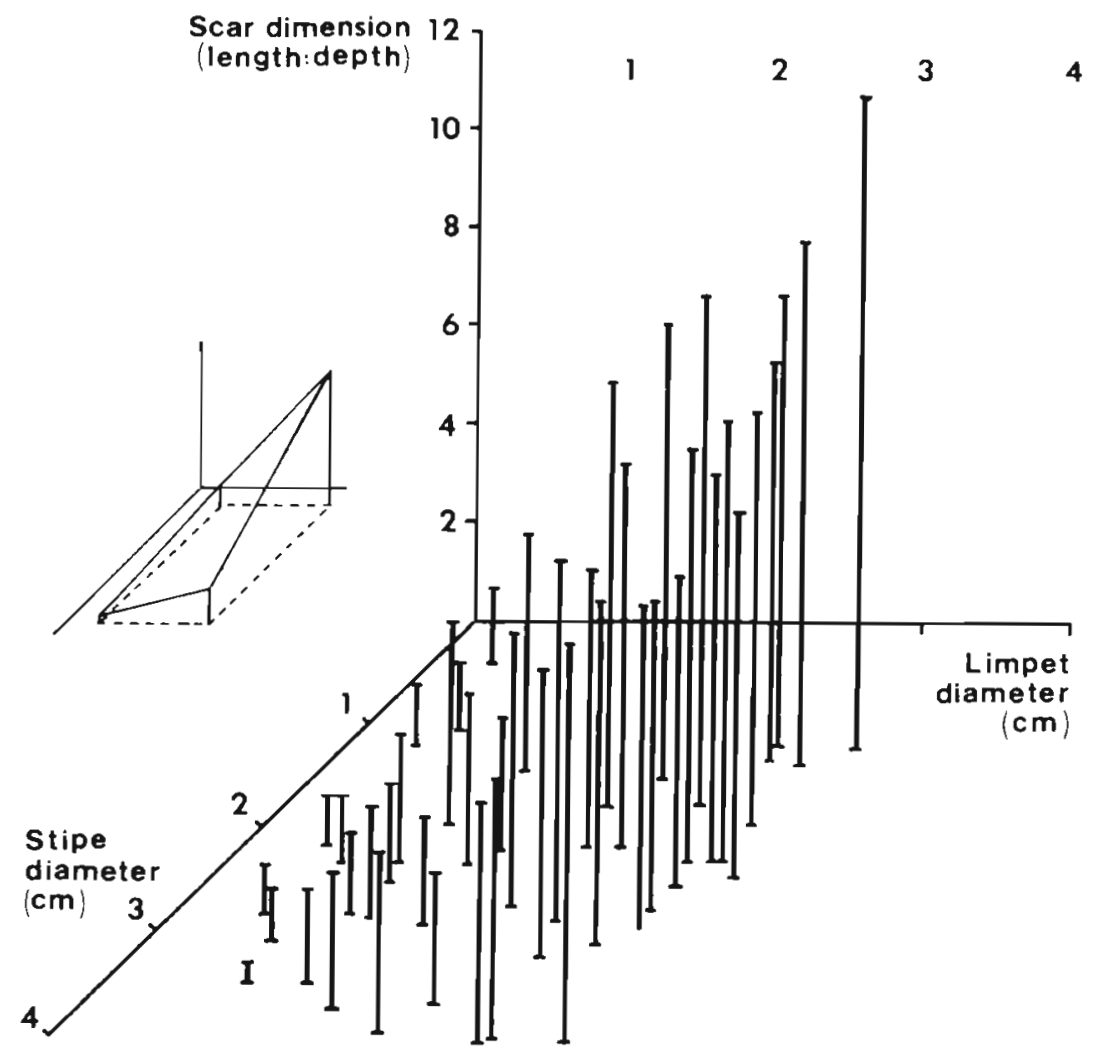

Fig. 4. Scurria scurra on Lessonia nigrescens Scar dimensions as function of limpet diameter and stipe diameter

sisted after 1 tidal cycle. In these stipes, losses increased at increasing distance from the first dichotomy. In stipes without previous limpet scars, stick losses occurred even below the first dichotomy; in these stipes, most cocktail sticks persisted in the 5 to $10 \mathrm{~cm}$ immediately above the holdfast.

In the experimental manipulation that consisted of placing 1 to 3 limpets in empty cavities there always remained only 1 limpet per cavity, irrespective of the number of limpets originally placed there. When 2 or 3 limpets of different sizes ( $<$ and $>2 \mathrm{~cm}$ ) were placed in the same cavity, the smaller limpet remained in the
1

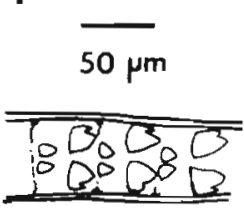

3

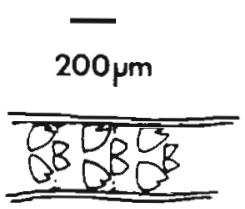

2

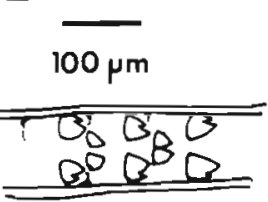

4

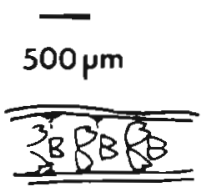

Fig. 5. Scurria scurra. Radular structure from individuals of (1) 0.17 ; (2) 0.44 ; (3) 1.25 and (4) $3.4 \mathrm{~cm}$ maximum shell diameter cavity in $30 \%$ of the cases; large limpets occupied the cavities in $70 \%$ of the cases.

The experiment combining increased load of limpets and decreased inter-stipe friction (Fig. 9) revealed several trends. With the exception of 1 stipe where 2 limpets near the holdfast survived, all limpets were lost in the 10 plants used as controls. On experimental plants (all but 1 stipe removed) limpets close to the holdfast $(<25 \mathrm{~cm}$ distance) survived moderately well, while those at a greater distance disappeared. In these stipes up to 8 cavities were excavated by surviving limpets, forming regular or irregular series of cavities

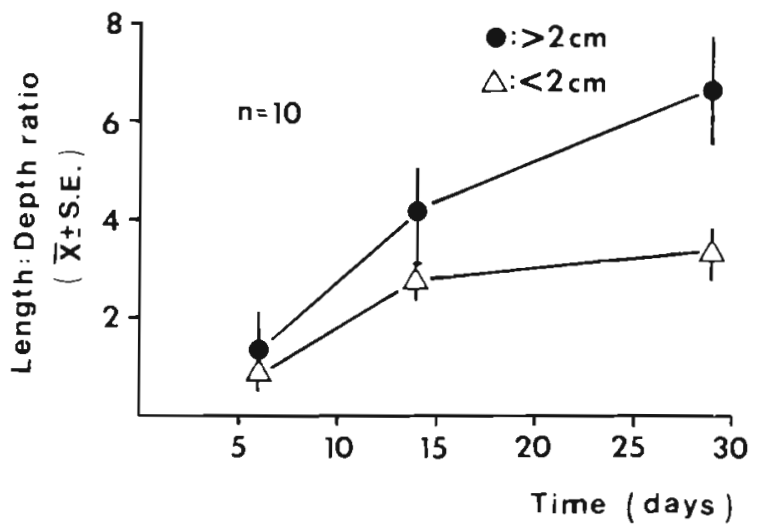

Fig. 6. Scurria scurra. Dimensions of newly excavated scars by 2 groups of limpets of different sizes 


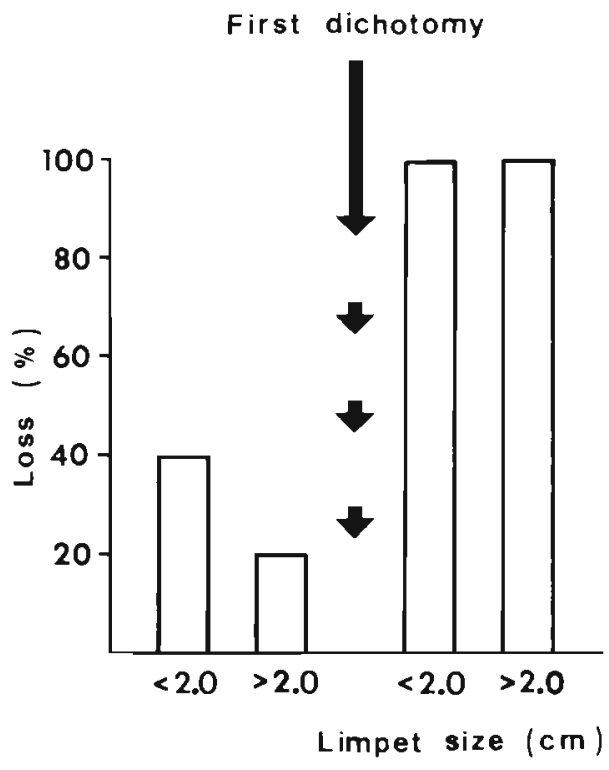

Fig. 7. Scurria scurra. Percentage of individuals lost when placed above (right) or below (left) the first dichotomy in the stipe of Lessonia nigrescens

(Fig. 10). The number of surviving limpets, as well as their residence times, increased in the proximal part of the stipe.

Results thus indicate that limpets settling above the first dichotomy are likely to be removed by inter-stipe friction induced by water movement. If this factor is reduced, the number of cavities bored along a stipe can be increased significantly. However, the tendency is that only 1 limpet per cavity remains.

TRE ATMENT

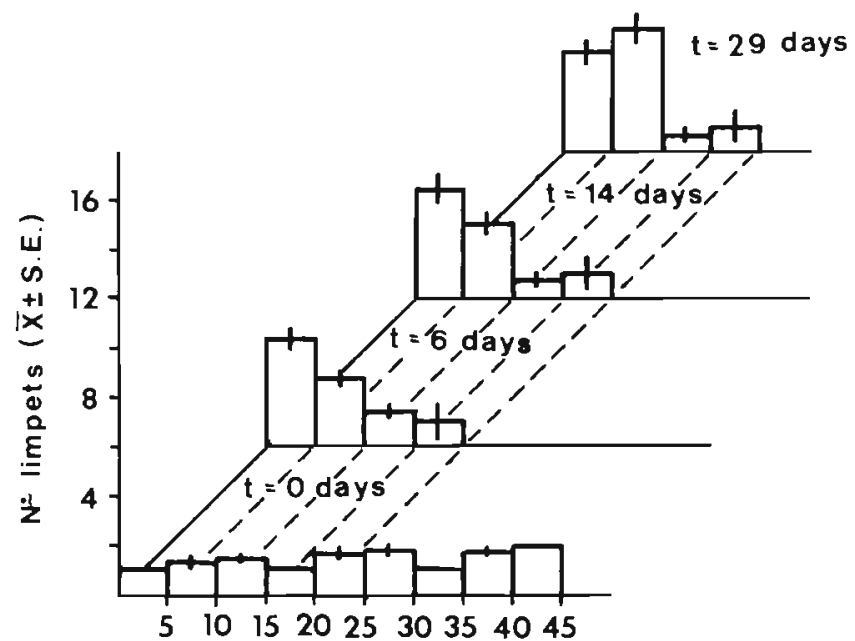

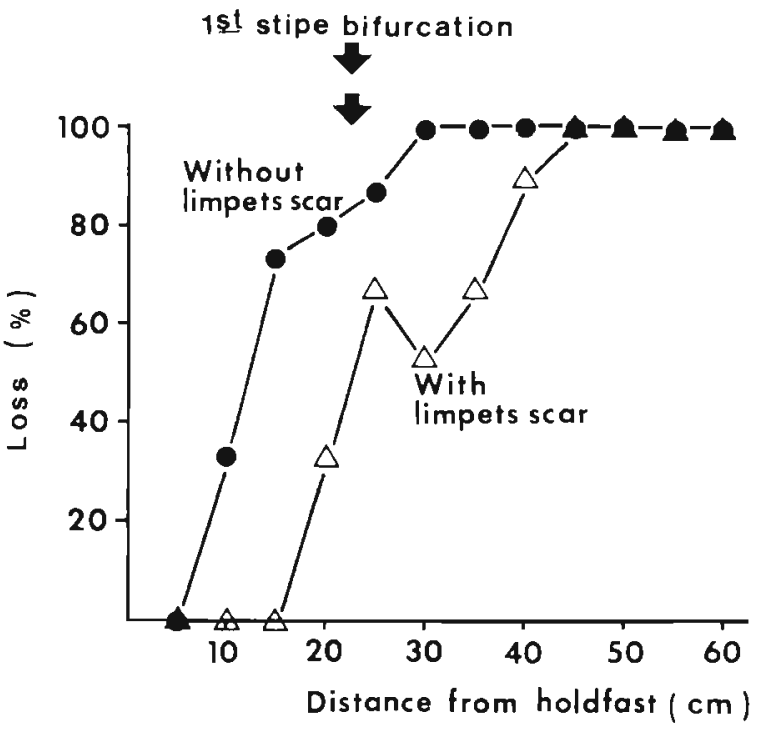

Fig. 8. Percent losses of cocktail sticks placed above and below the first stipe dichotomy along stipes of Lessonia nigrescens with and without limpet evidence ( $n=15$ for each percent calculation)

\section{DISCUSSION}

These results allow initial explanations of the patterns of distribution and abundance of Scurria scurra on the stipes of Lessonia nigrescens. In addition, the findings suggest a number of features, specific to this kelp-limpet association, which can be compared with information on the other 3 kelp-limpet associations that have been described (Table 1).

\section{CONTROL}

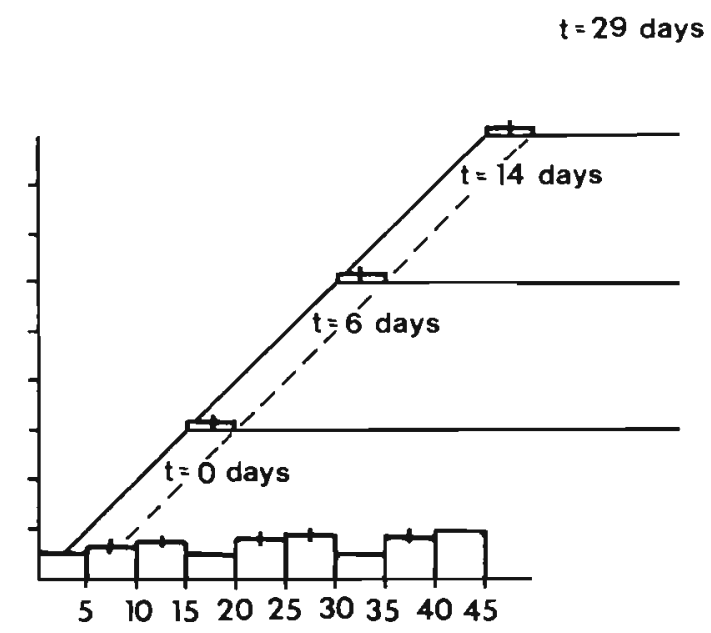

Distance from holdfast $(\mathrm{cm})$

Fig. 9. Scurria scurra. Survival of 10 to 15 individuals placed along the stipes of Lessonia nigrescens in plants with (treatment) and without (control) previous removal of other stipes 


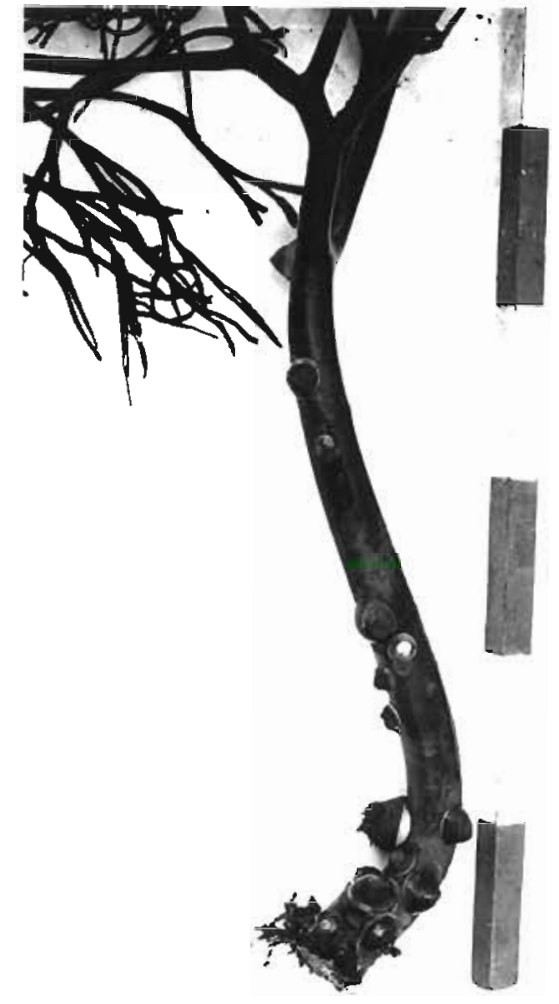

Fig. 10. Scurria scurra on Lessonia nigrescens. Experimentally induced increase in the number of limpets living along a stipe after removal of other stipes in the plant. (Measuring stick has $10 \mathrm{~cm}$ sections)

Like Helcion pellucidus (Graham \& Fretter 1947) and Notoacmea insessa (Black 1974), Scurria scurra lives in cavities excavated in stipes. However, in contrast to the above 2 species and similarly to Patella compressa (Branch 1975a), S. scurra can move out of the cavity during high tide, wandering along the stipe. We do not know the precise function of these excursions during high tides, but a search for food could be possible. The occurrence of limpets inside excavated cavities is often assumed to result from feeding activities of the limpets and, therefore, they are not expected to be motile. In the case of $S$. scurra this does not seem to be the case. The correlation between limpet size and cavity size could be interpreted as the result of the limpets feeding activities. However, some diet supplements could be provided through the consumption, during high tides, of epiphytes settling on the stipe surfaces.

In contrast to the age-related differences in excavating capacities described for Notoacmea insessa, individuals of Scurria scurra do not show age-related differences, either in radular structure or in excavating capacities. Since individuals smaller than $0.5 \mathrm{~cm}$ shell diameter live in smaller galleries excavated in the holdfasts whereas larger individuals live on the stipe, the above differences were expected in this species.
However, the only change encountered consisted of size of the radular teeth, proportional to overall increase in body size.

As in the case of the 3 other limpet-kelp associations, Scurria scurra has a precise location on the plant, below the first dichotomy. In addition, this limpet also has a precise location in the kelp bed, being most abundant close to the shore. Our experiment indicated that interstipe friction induced by water movement is the factor most likely to produce these precise patterns of distribution. Limpets can be removed as a result of increased water movement, as in the most wave-exposed seaward end of the kelp beds and on the distal ends of all stipes. Experimental data indicate, in addition, that inter-stipe friction restricts the habitats potentially usable by the limpet to the basal portions of some (70 to $80 \%)$ stipes in the plant. Chemical deterrents may also be involved in limpet distribution patterns (Choat \& Black 1979), but the pattern can be explained without them. Kelp-limpet interaction has often been characterized as a type of relationship where the herbivores consume only a minor amount of the plant biomass. Our results indicate that not all the algal biomass is available, because some environmental factors, such as water movement and inter-stipe friction, can restrict the presence of the herbivores to some portions of the plant.

Inter-stipe friction also seems to have a role in the determination of the number of limpets along a given stipe. The frequent occurrence of only 1 individual of Scurria scurra per stipe of Lessonia nigrescens parallels the situation described for Patella compressa on Ecklonia maxima (Branch 1975a, 1985). In the latter case, this pattern results from territorial behavior, and a similar mechanism was expected to operate with $S$. scurra. The substantial increase in the number of limpets living along a given stipe after the removal of the other stipes in the plant does not support the idea of territoriality in this case. Furthermore, if inter-stipe friction regulates the number of limpets along a given stipe, we can understand the occasional occurrence of stipes with 2 or 3 limpets.

We cannot rule out the possibility of intraspecific competition determining the number of individuals of Scurria scurra in each cavity. The existence of only 1 individual per cavity was a constant in our field observations and in the final result of some of our experiments. Surprisingly, though, in experiments involving the inclusion of more than 1 individual per cavity, the smaller limpet was the one staying in the cavity $30 \%$ of the time.

All species of limpets inhabiting kelps are subjected to mortality due to algal breakage. In the cases of Notoacmea insessa and Patella compressa, storms result in removal of plants, followed by death of the limpets by desiccation when they remain attached to seaweed cast ashore (Black 1974, 1976, Branch 1976, 
1985). In the case of Helcion pellucidus, the situation is different. The seaweed suffers predictable seasonal frond shedding. Even though a high mortality is associated with algal removal, many individuals remain attached to the holdfast after the seaweed is broken (Graham \& Fretter 1947, Kain \& Svendsen 1969, Vahl 1972). We lack detailed information on the fate of Scurria scurra after the breakage of the stipes of Lessonia nigrescens. Field observations indicated that a number of limpets remained attached to stipes cast ashore, and eventually died due to desiccation. However, our results suggest that at least $20 \%$ of the limpet population remains attached to the stipe stumps. Under some experimental conditions, stipe abscission results in regeneration of a new stipe (Santelices et al. 1980). However, we lack information on the grazing pressure exerted by the limpets and whether they allow regeneration. The finding that $S$ scurra maintains a roughly similar radular structure and unchanged excavating capacities throughout most of its life suggests that, if limpets were removed from their original stipe, they could complete excavation of a new home in any suitable stipe before long ( $30 \mathrm{~d})$. We do not know the time of residence of each limpet in each cavity. Empty cavities are readily filled up by outgrowth of the cortical tissue of $L$. nigrescens and cannot be used as estimates of this phenomenon.

Overall, a comparison of our results with information on other kelp-limpet associations indicate that generalizations can be extended to a few common features only. In general, although the limpets use the algae as specialized habitats, they do not damage the meristematic or reproductive algal tissues. Normally, the older stipes in the algae are the most affected by the limpets' activities. Limpet reproduction starts at an early age and is generally continuous throughout the year. Limpet longevity generally matches algal longevity.

Other characteristics, however, resist generalizations as they can be fixed and predictable in some associations and variable in others. These include the precise location of the limpet in the algal population or in the plant, age-related differences in radular structure or in the excavating capacity of limpets, ability to recruit to previously excavated cavities, evidence of territorial behavior and degree of limpet mortality due to algal removal. These characters seemingly represent outcomes of specific life history adjustments of each interacting partner in each association. Also they suggest independent origins of these associations. The lack of general predictability probably suggest great plasticity favouring the viability of each interaction in time.

This article was presented by Dr J. E. Winter, Valdivia, Chile
Acknowledgements. This study was part of a research seminar completed under a Ph. D. program in Ecology at the Facultad de Ciencias Biológicas, P. Universidad Católica de Chile. The first author thanks P. Universidad Católica de Chile and Fundación Andes, Chile, for scholarships awarded during the study period. The second author thanks George Branch for many stimulating discussions on kelps and limpets. We thank Dirección de Investigación, Pontificia Universidad Católica de Chile (grant 67/87 to B. Santelices) for the contribution of funds supporting this study. Our gratitude to $V$ Alcazar, R. Duran, M. Mendez and S. Navarrete for much help in the field. The preparation of this manuscript was completed while the second author was a visiting Professor and a Guggenheim Fellow at the Department of Botany, University of Hawaii. International Foundation for Science and Fundación Andes contributed additional funds and P. Universidad Católica de Chile granted sabbatical and study leave. His gratitude to all these Institutions for their support.

\section{LITERATURE CITED}

Black, R. (1974). Some biological interactions affecting intertidal population of the kelp, Egregia laevigata. Mar. Biol. 28: $189-198$

Black, R. (1976). The effects of grazing by limpets Acmaea insessa on the kelp. Egregia laevigata, in the intertidal zone. Ecology 57: 265-277

Branch, G. (1975a). Mechanism reducing intra-specific competition in Patella sp.: migration, differentiation, and territorial behaviour J. Anim. Ecol. 44: 575-600

Branch, G. (1975b). Intraspecific competition in Patella cochlear Born. J. Anim. Ecol. 44: 263-281

Branch, G. (1976). Interspecific competition experienced by South African Patella species. J. Anim. Ecol. 45: 507-529

Branch, G. (1985). Limpets: evolution and adaptation. In: Trueman, E. R., Clarke, M. R. (eds) The Mollusca, Vol. 10. Academic Press, London, p. 187-220

Choat, J., Black, R. (1979). Life histories of limpets and the limpet-laminarian relationship. J. exp. mar. Biol. Ecol. 41. $25-50$

Graham, A., Fretter, V. (1947). The life history of Patina pellucida (L.). J. mar. biol. Ass. U. K. 26: 590-601

Kain, J. M. (1963). Aspects of the biology of Laminaria hyperborea. II. Age, weight and length. J. mar. biol. Ass. U. K. 43: 129-151

Kain, J. M., Svendsen, P. (1969). A note on the behaviour of Patina pellucida in Britain and Norway. Sarsia 38: 25-30

Santelices, B., Castilla, J. C., Cancino, J., Schmiede, P. (1980). Comparative ecology of Lessonia nigrescens and Durvillaea antarctica (Phaeophyta) in Central Chile. Mar. Biol. 59: 119-132

Steneck, R. (1982). A limpet-coralline algae association: adaptation and defenses between a selective herbivory and its prey. Ecology 63: 507-522

Vahl, O. (1971). Growth and density of Patina pellucida (L.) (Gastropoda: Prosobranchia) on Laminaria hyperborea (Gunnerus) from Western Norway. Ophelia 9: 31-50

Vahl, O. (1972). On the position of Patina pellucida (L.) (Gastropoda) on the frond of Laminaria hyperborea. Ophelia 10: 1-9

Manuscript first received: June 13, 1988

Revised version accepted: February 24, 1989 